\title{
Lymphocyte phenotype during severe sepsis and septic shock
}

\author{
M Le Dorze ${ }^{1 *}$, V Tarazona $^{2}$, C Brumpt $^{3}, \mathrm{H}_{\text {Moins-Teisserenc }}{ }^{4}$, AC Lukaszewicz $^{1}$, D Payen $^{1}$ \\ From ESICM LIVES 2015 \\ Berlin, Germany. 3-7 October 2015
}

\section{Introduction}

Two major immuno-inflammatory phases are well documented during sepsis: an early active inflammatory phase regulated followed by a deactivated inflammatory phase leading to immunosuppression. Innate immunity, such as monocyte HLA-DR expression (mHLA-DR), has been shown constantly and rapidly decreased. Adaptive immunity modifications have been reported, this appeared less documented, particularly in comparison with healthy volunteers which have been rarely reported.

\section{Objectives}

The aim of this study is 1 - to describe lymphocyte phenotypes in healthy volunteers 2- to study the phenotype in early $(<\mathrm{D} 7)$ and late $(>\mathrm{D} 7)$ phases of severe sepsis 3to test the relation between lymphocyte phenotypes and prognosis.

\section{Methods}

Monocenter study on patients with severe sepsis and septic shock. Data recorded: demographic, clinical severity, blood cell count, mHLA-DR, lymphocyte phenotype (flow cytometry, CD3+, CD3+CD4+, CD3+CD8+, CD19 +, CD16+CD56+). Samples taken as part of routine care without additional blood collection and did not required patient's consent. Patients data compared with a historical group of healthy volunteers from the laboratory. Statistics: results expressed as median $\left(25^{\text {th }}-75^{\text {th }}\right.$ percentile), Mann-Whitney test, Pearson correlation.

\section{Results}

45 septic patients ( 9 severe sepsis, 36 septic shock), age 66 (52-85), sex (29M/16F), origin of sepsis (pulmonary $30 \%$, abdominal $35 \%$, others $30 \%$ ), SAPS2 at admission

1UMR INSERM 1160, University Paris 7, Department of Anesthesiology and Critical Care Lariboisiere Hospital, Paris, France

Full list of author information is available at the end of the article
51 (40-63), SOFA score (day of phenotype) 9 (5-13), overall mortality at day 7: $22 \%$ and day $28: 48 \%$, delay between the inflammatory insult and lymphocyte phenotype was 2 days (1-10). 48 healthy volunteers in the control group: age $42(31-55)$, sex $(24 \mathrm{M} / 24 \mathrm{~F})$. The overall lymphopenia in septic patients was $-37 \%$ compared to controls, mainly due to $\mathrm{CD} 4 \mathrm{~T}$ lymphocytes depletion (Table). This $\mathrm{T}$ lymphopenia was more marked in the early phase $(<7 \mathrm{D})$ than in the late phase $(>7 \mathrm{D})(\mathrm{p}=$ 0.006). Early lymphocyte phenotype was not associated with mortality at day 7; as was not late lymphocyte phenotype with mortality at day 28 . There was a correlation between lymphopenia and mHLA-DR (r0.55, p0.00009). There was no correlation between lymphocyte phenotype and severity scores.

\section{Conclusions}

In severe sepsis including shock, lymphopenia was predominant on CD4+ T lymphocytes, mainly at the early phase, in association with decreased expression of mHLA-DR, suggesting synergistic changes in innate and adaptive immunity. Such monitoring for innate and

Table 1

\begin{tabular}{lccc}
\hline & $\begin{array}{c}\text { Control group } \\
(\mathbf{n}=\mathbf{4 8})\end{array}$ & $\begin{array}{c}\text { Sepsis group } \\
(\mathbf{n}=\mathbf{4 5})\end{array}$ & $\mathbf{p}$ \\
\hline $\begin{array}{l}\text { Lymphocytes } \\
\text { (n/mm3) }\end{array}$ & $1586(1372-1991)$ & $1000(660-1495)$ & 0.12 \\
\hline $\begin{array}{l}\text { T Lymphocytes } \\
\text { CD3+ }\end{array}$ & $1182(949-1524)$ & $609(258-1038)$ & $<0.05^{*}$ \\
\hline CD3+CD4+ & $685(595-1035)$ & $378(156-668)$ & $<0.05^{*}$ \\
\hline CD3+CD8+ & $431(301-508)$ & $200(90-338)$ & 0.33 \\
\hline $\begin{array}{l}\text { B Lymphocytes } \\
\text { CD19+ }\end{array}$ & $143(96-338)$ & $149(75-252)$ & 0.14 \\
\hline NK CD16+CD56+ & $161(114-268)$ & $161(114-268)$ & 0.83 \\
\hline mHLA-DR (AB/C) & $39970(35480-46480)$ & $5700(3545-10072)$ & $<0.05^{*}$ \\
\hline
\end{tabular}

[Lymphocyte Phenotype]. 
adaptive immunity may help to decide the suitable drug to boost immunity, such as IFN $\gamma$ or IL-7.

\section{Authors' details}

${ }^{1}$ UMR INSERM 1160, University Paris 7, Department of Anesthesiology and Critical Care Lariboisiere Hospital, Paris, France. ${ }^{2}$ UMR INSERM 1160,

University Paris, Department of Anesthesiology and Critical Care Lariboisiere Hospital, Paris, France. ${ }^{3}$ Hematology Lariboisiere Hospital, University Paris 7 ,

Paris, France. ${ }^{4}$ Immunology Saint-Louis Hospital, University Paris 7, Paris,

France.

Published: 1 October 2015

\section{References}

1. Nature Rev Immunol 2013, 13(12):862-74.

2. Crit Care 2012, 16(3):R112.

3. J Immunol 2001, 166:6952-6963.

doi:10.1186/2197-425X-3-S1-A622

Cite this article as: Le Dorze et al: Lymphocyte phenotype during

severe sepsis and septic shock. Intensive Care Medicine Experimental 2015

3(Suppl 1):A622.

\section{Submit your manuscript to a SpringerOpen ${ }^{\mathcal{O}}$ journal and benefit from:}

- Convenient online submission

- Rigorous peer review

- Immediate publication on acceptance

- Open access: articles freely available online

- High visibility within the field

- Retaining the copyright to your article

Submit your next manuscript at $\gg$ springeropen.com 